\title{
Kearifan Lokal Tambang Rakyat sebagai Wujud Ecoliteracy di Kabupaten Bangka
}

\author{
Derita Prapti Rahayu \\ Fakultas Hukum Universitas Bangka Belitung \\ Kampus Terpadu Universitas Bangka Belitung, Desa Balunijuk, \\ Kec. Merawang, Kab. Bangka \\ deritapraptir@yahoo.com
}

\begin{abstract}
The issues studied in this research included, first: how to build ecoliteracy for a sustainable environment? Second, how the local wisdom in people mining as a form of ecoliteracy in Bangka is. This research used a socio-legal approach with the techniques of data collection through documentation, participative observation and interviews. The result of the research concluded that first: ecoliteracy development for a sustainable environment can be done by reviewing the local wisdom of local communities. The participation of community in protecting and preserving local wisdom is in line with Article 70 paragraph (3) letter (e) of Law No. 32 Year 2009. Second, the local wisdom of people mining in the form of ampak tin is an essential element to build ecoliteracy in Bangka. The local wisdom in people mining in the form of ampak tin needs to be strengthened in the form of regulations of local governments to prevent Bangka Regency from the threat of environmental damages. In addition, the ampak tin must be preserved and used as a form ecoliteracy in Bangka for a sustainable environment.
\end{abstract}

Key words: Local wisdom, people mining, ecoliteracy

\begin{abstract}
Abstrak
Permasalahan dalam penelitian ini, pertama: bagaimanakah membangun ecoliteracy untuk lingkungan berkelanjutan? Kedua, bagaimanakah kearifan lokal tambang rakyat sebagai wujud ecoliteracy di Kabupaten Bangka. Penelitian ini menggunakan pendekatan sosio-legal dengan teknik pengambilan data melalui dokumentasi, observasi partisipatif dan wawancara. Hasil penelitian menyimpulkan bahwa, pertama: pembangunan ecoliteracy untuk lingkungan berkelanjutan dapat dilakukan dengan cara meninjau kearifan lokal masyarakat setempat. Partisipasi masyarakat dalam melindungi dan melestarikan kearifan lokal sejalan dengan Pasal 70 ayat (3) huruf (e) UU No. 32 Tahun 2009. Kedua, kearifan lokal tambang rakyat berupa timah ampak merupakan unsur penting untuk membangun ecoliteracy di Kabupaten Bangka. Kearifan lokal tambang rakyat berupa timah ampak ini perlu diperkuat dalam bentuk regulasi dari pemerintah daerah untuk mencegah Kabupaten Bangka dari ancaman kerusakan lingkungan.Selain itu, timah ampak harus dilestarikan dan dipergunakan sebagai wujud ecoliterac ydi Kabupaten Bangka untuk lingkungan berkelanjutan.
\end{abstract}

Kata kunci; Kearifan lokal, tambang rakyat, ecoliteracy. 


\section{Pendahuluan}

Penelitian ini dilakukan di Wilayah Kabupaten Bangka, salah satu penghasil timah di Indonesia ${ }^{1}$. Bangka merupakan kabupaten di Propinsi Kepulauan Bangka Belitung2 dengan luas Wilayah 3.028,794 $\mathrm{km}^{2}$ atau 3.028.794,693 Ha. Wilayah Kabupaten Bangka terletak di Pulau Bangka. Kabupaten ini memiliki luas wilayah lebih kurang 2.950,68 km² atau 295.068 Ha. Secara administratif wilayah Kabupaten Bangka berbatasan langsung dengan daratan wilayah kabupaten/kota lainnya di Propinsi Kepulauan Bangka Belitung, yaitu dengan wilayah Kota Pangkalpinang, Kabupaten Bangka Tengah dan Kabupaten Bangka Barat serta Laut Natuna.

Kabupaten Bangka terdiri dari 8 Kecamatan yaitu Kecamatan Sungailiat dengan luas wilayah 146,38 km², Kecamatan Pemali dengan luas wilayahnya 127,87 $\mathrm{km}^{2}$, Kecamatan Bakam dengan luas wilayah 488,10 km², Kecamatan Belinyu dengan luas wilayah 546,50 km², Kecamatan Mendo Barat dengan luas wilayah 570,46 km², Kecamatan Merawang dengan luas wilayahnya 164,40 km², Kecamatan Puding Besar dengan luas wilayah 383,29 km², Kecamatan Riau Silip dengan luas wilayah $533,68 \mathrm{~km}^{2} .^{3}$

Pertambangan rakyat di Bangka adalah pertambangan mineral logam timah yang mulai ada sejak 1998,4 karena sebelumnya rakyat dilarang untuk melakukan penambangan. Istilah yang berkembang dan dikenal oleh masyarakat Kabupaten Bangka adalah Tambang Timah Inkonvensional (TI).

Aktivitas penambangan, apapun bentuknya pasti tidak lepas dari persoalan lingkungan hidup, karena pada hakekatnya melakukan penambangan berarti mengubah tatanan alam. Kapan dan dimanapun kegiatan penambangan itu

${ }^{1}$ Erwiza Erman, Menguak Sejarah Timah Bangka Belitung, Penerbit Ombak, Yogyakarta, 2009, hlm. 74,periksa juga Siti Maimunah, Negara Tambang Dan Masyarakat Adat, Perspektif HAM Dalam Pengelolaan Pertambangan Yang Berbasis Lingkungan Dan Kearifan Lokal, Intrans Publising, Malang, hlm. 146

2 Tepatnya pada tahun 2000 Propinsi Kepulauan Bangka Belitung berdiri lepas dari Sumatera Selatan sekaligus merupakan propinsi yang ke-31 di Indonesia, berdasar Undang-Undang No. 27 Tahun 2000 tentang Pembentukan Propinsi Kepulauan Bangka Belitung.

${ }^{3}$ Geografis Dan Wilayah Pemerintah Daerah Kapaten http://www.bangka.go.id/content.php?id_content=kondisi_geografis, diakses 05 Maret 2015.

${ }^{4}$ Iskandar Zulkarnain, Konflik di Kawasan Pertambangan Timah di Bangka Belitung, Penerbit LIPI Press, 2005, Jakarta, hlm.73. Dikutip juga oleh Tri Hayati, , Perizinan Pertambangan Di Era Reformasi Pemerintahan Daerah Studi Tentang Periqinan Pertambangan Timah di Pulau Bangka, Disertasi UI, 2011, http:/ / lib.ui.ac.id/ file?file=digital/ 20305841 D\%201270-Perizinan\%20pertambangan-full\%20text.pdf, diakses tanggal 07 Oktober 2014. 
dilakukan, akan bersentuhan langsung dengan perusakan lingkungan. ${ }^{5}$ Walaupun demikian tetap harus diperhatikan dalam pengusahaan pertambangan mengenai aspek kelestarian lingkungan, ${ }^{6}$ sehingga terwujud masyarakat berkelanjutan yang oleh Capra disebut dengan ecoliteracy, sebagai keadaan dimana orang telah memahami prinsip-prinsip ekologi dan hidup sesuai dengan prinsip-prinsip lingkungan dalam menata kehidupan bersama umat manusia di bumi. ${ }^{7}$ Pada dasarnya ecoliteracy mengajak kita untuk memafaatkan alam lingkungan sesuai dengan kebijaksanaan lingkungan yaitu kearifan lokal berkaitan dengan pengelolaan lingkungan.

Di negara Indonesia, diakui adanya kearifan lokal dalam mengelola lingkungan hidup, yaitu termuat dalam Undang-Undang No. 32 Tahun 2009 tentang Perlindungan dan Pengelolaan Lingkungan Hidup (selanjutnya menggunakan istilah UUPPLH). Pasal 1 angka 30 UUPPLH menjelaskan kearifan lokal adalah nilai-nilai luhur yang berlaku dalam tata kehidupan masyarakat untuk antara lain melindungi dan mengelola lingkungan hidup secara lestari. Kearifan lokal juga menjadi salah satu asas dalam perlindungan dan pengelolaan lingkungan hidup yang dimuat dalam Pasal 2 huruf (1) UUPPLH dan diperjelas dalam penjelasannya, yang dimaksud dengan asas kearifan lokal adalah bahwa dalam perlindungan dan pengelolaan lingkungan hidup harus memperhatikan nilai-nilai luhur yang berlaku dalam tata kehidupan masyarakat.

Ketentuan mengenai kearifan lokal ini juga menjadi dasar dalam penyusunan Rencana Perlindungan dan Pengelolaan Lingkungan Hidup (RPPLH) yang harus memperhatikan kearifan lokal (Pasal 9 ayat (2) huruf (d) UUPPLH). Undang-Undang ini juga memberikan pengaturan mengenai peran masyarakat dalam perlindungan dan pengelolaan lingkungan hidup yang dilakukan untuk

5Perusakan lingkungan hidup adalah tindakan orangyang menimbulkan perubahan langsung atautidaklangsung terhadap sifat fisik, kimia, dan/atauhayati lingkungan hidup sehingga melampauikriteria baku kerusakan lingkungan hidup, Kerusakan lingkungan hidup adalah perubahan langsung dan/atau tidak langsung terhadap sifat fisik, kimia, dan/atau hayati lingkungan hidup yang melampaui kriteria baku kerusakan lingkungan hidup (Pasal 1 angka 16 dan 17 Undang-Undang Nomor 32 Tahun 2009 Tentang Perlindungan dan Pengelolaan Lingkungan Hidup.

'Pelestarian fungsi lingkungan hidup adalah rangkaian upaya untuk memelihara kelangsungan daya dukung dan daya tampung lingkungan hidup. Pasal 1 (1) Nomor 32 Tahun 2009 Tentang Perlindungan dan Pengelolaan Lingkungan Hidup.

${ }^{7}$ Sonny Keraf, Filsafat Lingkungan Hidup Alam Sebagai Sebuah Sistem Kebidupan, Kanisius, Yogyakarta, 2014, hlm. 127. 
mengembangkan dan menjaga budaya dan kearifan lokal dalam rangka pelestarian fungsi lingkungan hidup (Pasal 70 ayat (3) huruf (e) UUPPLH).

Sikap terhadap alam dan lingkungan tentu saja tidak dapat dilepaskan dari latar belakang kebudayaan sebelumnya. Sastrosupeno menjelaskan bahwa hubungan antara manusia dengan alam dan lingkungan sangat dekat dan erat sehingga tumbuh suatu kepercayaan, nilai lokal, atau tradisi, hal itu berkaitan dengan aturan-aturan moral lokal yang diketahui oleh masyarakat dan merupakan wujud dari kearifan lokal. ${ }^{8}$

Sesuai dengan pendapat Gadgil dan Barkes, bahwa kearifan lokal tidak dapat dipisahkan dari unsur-unsur aturan lokal, tradisi lokal, adat istiadat atau nilai-nilai budaya ${ }^{9}$ yang merupakan bukti harmonisnya hubungan antara masyarakat dan lingkungan. Pengertian kebahasaan kearifan lokal, berarti kearifan setempat (local wisdom) yang dapat dipahami sebagai gagasan-gagasan lokal yang bersifat bijaksana, penuh kearifan, bernilai, tertanam dan diikuti oleh warga masyarakatnya. ${ }^{10}$

Pentingnya kearifan lokal sebagai dasar dalam pengambilan keputusan pertambangan dalam menekan potensi kerusakan lingkungan ditunjukkan pula oleh hasil penelitian Research Center for Politics an Government Departemen Politik Gadjah Mada di Banyuwangi, Jawa Timur tahun 2015 yang menemukan tambang emas di Gunung Tumpang Pitu, Desa Sumberagung, Kecamatan Pesanggaran sebagai benteng alam yang melindungi masyarakat Tumpang Pitu dari bencana. Oleh karena itu, terlalu beresiko jika kondisi alam itu diubah oleh kegiatan pertambangan sehingga kerugian yang ditimbulkan akan lebih besar dibandingkan manfaat tambang yang dinikmati.11 Uraian di atas menegaskan bahwa kelestarian lingkungan tetap menjadi prioritas dalam pertambangan berdasar pada kearifan lokal masyarakat.

8 Sastrosupeno, S, Manusia, Alam dan Lingkungan.Proyek Penulisan dan Penerbitan Buku/Majalah Pengetahuan Umum dan Profesi.Departemen Pendidikan dan Kebudayaan, 1984, hlm. 12

${ }^{9}$ B.B.Mitchell Setiawan dan Dwita Hadi Rahmi, Pengelolaan Sumber Daya dan Lingkungan, Gajah Mada University Press, Yogyakarta, 2007, hlm. 25.

${ }^{10}$ Kementerian Kebudayaan Dan Pariwisata Republik Indonesia, Kearifan Lokal Di Tengah Modernisasi, Pusat Penelitian Dan Pengembangan Kebudayaan Badan Pengembangan Sumber Daya Kebudayaan dan Pariwisata Kementerian Kebudayaan Dan Pariwisata Republik Indonesia, 2011, hlm. IX.

11“Pertambangan, Pengetahuan Lokal Terabaikan”, Kompas, Rabu, 27 Januari 2016, hlm. 23 


\section{Rumusan Masalah}

Permasalahan dalam penelitian ini antara lain, pertama: bagaimanakah membangun ecoliteracy untuk lingkungan berkelanjutan? Kedua, bagaimanakah kearifan lokal tambang rakyat sebagai wujud ecoliteracy di Kabupaten Bangka?

\section{Tujuan Penelitian}

Tujuan penelitian ini adalah untuk mengetahui: pertama, cara membangun ecoliteracy untuk lingkungan berkelanjutan. Kedua, kearifan lokal tambang rakyat sebagai wujud ecoliteracy di Kabupaten Bangka.

\section{Metode Penelitian}

Penelitian ini menggunakan pendekatan socio-legal,12 yaitu objek penelitian tetap berupa hukum yaitu peraturan perundangan-undangan terkait tambang rakyat dan lingkungan dengan digunakannya metode dan teori ilmu-ilmu sosial untuk membantu peneliti dalam melakukan analisis. Penelitian ini merupakan penelitian kualitatif ${ }^{13}$ dengan teknik pengambilan data melalui dokumentasi, observasi partisipatif, dan wawancara yang mendalam dengan para key informan.

Jenis data dalam penelitian ini adalah data primer dan data sekunder yang berasal dari bahan hukum primer dan bahan hukum tersier. Data primer diperoleh dari penelitian di lapangan, dengan mewawancara sejumlah key informan ${ }^{14}$, yaitu: 1. Penambang rakyat/ penambang timah inkonvensional (TI) yakni: Darso dari Kampung Kimak, Mang Toha dan Mang Bahan dari Belinyu, Amad dari Mabet. 2.

12 Esmi Warassih, Bahan Kuliah Metodologi Penelitian Hukum, Program Pascasarjana Fakultas Hukum Universitas Islam Indonesia, 2007, hlm.5.

${ }^{13}$ Dimaksudkan agar peneliti dapat mengungkapkan secara lebih mendalam fenomena sosial dan hukum karena akan mempermudah peneliti untuk menyesuaikan dengan keadaan atau berhadapan dengan kenyataan ganda. Esensinya adalah sebagai sebuah metode pemahaman atas keunikan, dinamika dan hakikat holistik dari kehadiran manusia dan interaksinya dengan lingkungan. Penelitian kualitatif bersifat kompleks dan luas, yang bermaksud memberikan makna atas fenomena secara holistik dan peneliti merupakan instrumen kunci sehingga harus berperan aktif dalam keseluruhan proses penelitian. Lebih jelas lihat Sudarwan Danim, Menjadi Peneliti Kualitatif, Pustaka Setia, Bandung, 2002, hlm.35.

${ }^{14}$ Informan kunci ditentukan berdasarkan pengetahuan dan pengalaman informan, lihat Purnawan D. Negara, Dekonstruksi kebijakan Pengelolaan Kawasan Tengger Berbasis Nilai Komunal Ekologios Dalam Perspektif Sosio Legal, Disertasi Program Doktor Ilmu Hukum, Undip, 2014, hlm. 54 
penyelenggara pemerintah daerah Kabupaten Bangka terkait kelembagaan WPR, yakni Staf ahli Badan Lingkungan Hidup Kabupaten Bangka yaitu Pak Sanusi dan Pak Endang Supriyadi, Staf ahli Dinas Pertambangan dan Energi Kabupaten Bangka yaitu Pak Amir, Staf ahli Dinas Pariwisata dan Budaya Kabupaten Bangka yaitu Pak Ali Usman, Staf ahli Badan Perencanaan Pembangunan Daerah Bangka Staf ahli Biro Hukum Kabupaten Bangka, Biro Hukum DPRD Kabupaten Bangka; 3. Beberapa tokoh masyarakat khususnya Dukon timah (istilah lokal) yakni Pak Fauzi Kampung Kace, Yuk Tutik Belinyu, Mang Bahan, Aji Sop, Ahmad Darli dan Zarkasi Kampung Dalil, Amang Kelurahan Sungailiat, Ramli Ngadjum Kampung Kelapa Melayu Jering, Pak Hanafi Kampung Mengkubung Belinyu; 4. Masyarakat biasa yang bukan penambang dan bukan dari Pemda yakni Ustadz Aan kampung Dalil, Pak Ferhad dari Mentok, Pak Deki dari Pangkalpinang, Pak Darmawan dari Sungailiat dari masyarakat, pelaku tambang rakyat dan para pengambil kebijakan.

Data sekunder dilakukan melalui studi pustaka maupun dokumendokumen berasal dari bahan hukum primer dan bahan hukum sekunder. Bahan hukum primer yaitu UUDNRI 1945, Undang-Undang No. 23 Tahun 1997 tentang Ketentuan Ketentuan Pokok Pengelolaan Lingkungan Hidup (UUPPLH) dan beberapa undang-undangan terkait dengan kearifan lokal yaitu Undang-Undang No. 27 Tahun 2007 tentang Pengelolaan Wilayah Pesisir Dan Pulau-Pulau Kecil', Undang-Undang Nomor 13 Tahun 2012 tentang Keistimewaan Daerah Istimewa Yogyakarta, Undang-Undang Nomor 6 Tahun 2014 tentang Desa, Undang-Undang No. 18 Tahun 2012 tentang Pangan, Undang-Undang 32 Tahun 2014 tentang Kelautan, Matriks I, Pembagian Urusan Pemerintahan Konkuren Antara Pemerintah Pusat Dan Daerah Provinsi Dan Daerah Kabupaten/Kota, Lampiran Undang-Undang Republik Indonesia Nomor 23 Tahun 2014 Tentang Pemerintahan Daerah Pembagian Urusan Pemerintahan Konkuren Antara Pemerintah Pusat Dan Daerah Provinsi Dan Daerah Kabupaten/Kota.

Bahan hukum sekunder diperoleh dengan menggunakan studi kepustakaan buku-buku literatur dan dokumen-dokumen resmi yang berkaitan dengan penelitian ini. Bahan hukum tersier, atau bahan hukum penunjang yaitu bahan hukum yang akan memberikan petunjuk informasi/penjelasan terhadap bahan 
hukum primer dan bahan hukum sekunder, seperti kamus hukum, indeks majalah hukum, jurnal hukum dan lain-lain.

Lokasi penelitian dilakukan di wilayah Kabupaten Bangka karena merupakan salah satu penghasil timah terbesar di Propinsi Kepulauan Bangka Belitung sehingga representasi kabupaten lainnya propinsi ini. Wilayah yang dipilih dengan pertimbangan daerah yang banyak terdapat TI yaitu daerah Kecamatan Sungailiat, Belinyu, Bakam dan wilayah yang tidak terdapat TI yaitu Kecamatan Bakam dan sebagian Wilayah Kecamatan Sungailiat. Kabupaten ini memiliki luas wilayah lebih kurang 2.950,68 Km2 atau 295.068 Ha. Secara administratif wilayah Kabupaten Bangka berbatasan langsung dengan daratan wilayah kabupaten/kota lainnya di Propinsi Kepulauan Bangka Belitung, yaitu dengan wilayah Kota Pangkalpinang, Kabupaten Bangka Tengah dan Kabupaten Bangka Barat serta Laut Natuna, dengan jumlah penduduk pada akhir tahun 2007 memiliki jumlah penduduk 242.010 jiwa. ${ }^{15}$

\section{Hasil Penelitian dan Pembahasan}

\section{Membangun Ecoliteracy untuk Lingkungan Berkelanjutan}

Apabila direnungkan dan dikaji secara mendalam makna slogan; "bumi ini adalah pinjaman generasi sekarang dari generasi yang akan datang" sesungguhnya merupakan peringatan (warning) bagi semua pihak yang terkait dengan pengelolaan sumber daya nasional. Khusus bagi pengusahaan bahan galian, perlu diiingat bahwa pengusahaan bahan galian secara berlebihan di masa sekarang tanpa mematuhi kaidah-kaidah hukum lingkungan, akan menjadi beban berat bagi generasi yang akan datang. Generasi penerus bangsa Indonesia akan menjadi generasi penanggung beban saja. Hal seperti ini tentu tidak berlaku secara khusus di negara tertentu saja, melainkan akan terjadi di semua negara yang melakukan langkah penanganan serupa, terutama sekali dalam pengusahaan bahan mineral untuk tujuan dan kepentingan yang bersifat sesaat. ${ }^{16}$

\footnotetext{
${ }^{15}$ Bagian Pemerintahan Setda Kabupaten Bangka.

${ }^{16}$ Ibid, hlm. 120-121
} 
Lingkungan hidup merupakan anugerah Tuhan Yang Maha Esa yang wajib dilestarikan dan dikembangkan kemampuannya agar tetap dapat menjadi sumber penunjang hidup bagi manusia dan makluk hidup lainnya demi kelangsungan dan peningakatan kualitas hidup itu sendiri. ${ }^{17}$ Secara ekologis, manusia adalah bagian dari lingkungan hidup. Komponen yang ada di sekitar manusia yang sekaligus sebagai sumber mutlak kehidupannya merupakan lingkungan hidup manusia. Lingkungan hidup inilah yang menyediakan berbagai sumber daya alam yang menjadi daya dukung bagi kehidupan manusia dan komponen lainnya. Sumber daya alam adalah segala sesuatu yang terdapat di alam yang berguna bagi manusia, untuk memenuhi kebutuhan hidupnya baik untuk masa kini maupun masa mendatang. Kelangsungan hidup manusia tergantung dari keutuhan lingkungannya, sebaliknya keutuhan lingkungan tergantung bagaimana kearifan manusia dalam mengelolanya. ${ }^{18}$

Saat ini mulai banyak muncul gerakan atau kelompok yang memandang dan memperlakukan alam semesta ini secara keseluruhan dan bukan parsial. Selama tigapuluh tahun terakhir, krisis lingkungan mendorong berlangsungnya proses "penghijauan pemikiran religius ketika para pemikir religius dari berbagai tradisi mulai memberikan tanggapan secara bermakna pada semakin besarnya kesadaran tentang makhluk yang begitu rapuh, mudah rusak, dan saling bergantung. ${ }^{19}$ Meskipun banyak tradisi religius memiliki cukup banyak sumber, namun belum banyak yang telah mengembangkan sepenuhnya etika lingkungan yang sistematis yang relevan dengan masalah-masalah kontemporer. Banyak hal yang muncul dan krisis yang luar biasa besar dari hal yang disebutkan di atas, oleh karena itu menjelang 1970-an muncul sebuah gerakan eko-keadilan yang berupaya mengintegrasikan ekologi, keadilan. ${ }^{20}$

Terdapat banyak konsensus tentang pentingnya aspek religius dalam bertindak menghadapi masalah-masalah lingkungan, dan tampak jelas bahwa

\footnotetext{
17 Penjelasan Umum dalam Undang-Undang No. 23 Tahun 1997 tentang Ketentuan Ketentuan Pokok Pengelolaan Lingkungan Hidup.

${ }^{18}$ Kementerian Negara Lingkungan Hidup, Majalah Serasi, Deputi Bidang Komunikasi Lingkungan dan Pemberdayaan Masyarakat, Jakarta,Januari, 2006, hlm. 35

${ }_{19}$ Audrey R. Chapman, Rodney L. Petersen, Barbara Smith Moran, Bumi yang Terdesak; Perspektif Imu dan Agama Mengenai Konsumsi, Populasi, dan Keberlanjutan, Mizan, Bandung, 2007, hlm. 153

${ }^{20} \mathrm{Ibid}$.
} 
perjuangan untuk mengintegrasikan ekologi, keadilan (masyarakat) dan keimanan menjadi pemikiran yang permanen pada masa-masa yang mendatang. Meminjam pemikiran ekologis Fritjof Capra tentang jaring-jaring kehidupan di alam semesta ini bahwa sesungguhnya ada relasi timbal balik antara manusia dengan alam. Manusia bukanlah penguasa alam semesta melainkan manusia hanyalah bagian dari jaring-jaring kehidupan yang ada di alam semesta ini. Apapun yang manusia lakukan terhadap jaring-jaring kehidupan ini pada akhirnya akan berimbas pada manusia itu sendiri sebagai bagian dari jaring-jaring kehidupan tersebut. ${ }^{21}$

Konsep Capra sebenarnya banyak terinspirasi oleh gaya pemikiran keseimbangan dan keharmonian antara dualitas yin dan yang. Capra mengambil contoh jaring-jaring kehidupan ini dalam kasus rantai makanan, ada ketergantungan satu organisme terhadap organisme lain yang mengarah pada kondisi mutualisme. Capra kemudian menuangkan gagasannya tentang pengelolaan lingkungan ini ke dalam konsep besar, yaitu ecoliteracy. ${ }^{22}$

Ecoliteracy lebih mengarahkan pada upaya membentuk kesadaran akan pentingnya lingkungan hidup bagi keberlanjutan jaring-jaring kehidupan. Ecoliteracy, bisa diartikan sebagai situasi melek huruf, paham, atau memiliki pengertian terhadap bekerjanya prinsip-prinsip ekologi dalam kehidupan bersama di bumi. Jadi apa yang perlu dipahami dari ecoliteracy adalah wisdom of nature (kebijaksanaan alam) yang digambarkan oleh Fritjof Capra sebagai kemampuan sistem-sistem ekologis planet bumi mengorganisir dirinya sendiri melalui cara-cara

${ }^{21}$ Fritjof Capra, Jaring-Jaring Kehidupan: Visi Baru Epistemologi dan Kehidupan, Fajar Pustaka Baru, Yogyakarta, 2002, hlm. vii.

${ }^{22}$ Antroposentrisme adalah teori etika lingkungan yang memandang manusia sebagai pusat dari sistem alam semesta. Manusia dan kepentingannya dianggap yang paling menentukan dalam tatanan ekosistem dan dalam kebijakan yang diambil dalam kaitan dengan alam, baik secara langsung atau tidak langsung. Nilai tertinggi adalah manusia dan kepentingannya. Hanya manusia yang mempunyai nilai dan mendapat perhatian. Segala sesuatu yang lain di alam semesta ini hanya akan mendapat nilai dan perhatian sejauh menunjang dan demi kepentingan manusia. Oleh karena itu, alam pun dilihat hanya sebagai objek, alat dan sarana bagi pemenuhan kebutuhan dan kepentingan manusia. Alam hanya alat bagi pencapaian tujuan manusia. Alam tidak mempunyai nilai pada dirinya sendiri. Biosentrisme menolak argumen antroposentrisme. Bagi biosentrisme, tidak benar bahwa hanya manusia yang mempunyai nilai. Alam juga mempunyai nilai pada dirinya sendiri lepas dari kepentingan manusia. Menurut Susilo bahwa biosentrisme mengajarkan tentang hidup dengan menghargai banyak spesies, mengajari bagaimana memandang lingkungan dengan cara berfikir fundamental. Ekosentrisme merupakan kelanjutan dari teori etika lingkungan biosentrisme. Sebagai kelanjutan dari biosentrisme, ekosentrisme sering disamakan begitu saja dengan biosentrisme karena ada banyak kesamaan di antara kedua teori ini. Kedua teori ini mendobrak cara pandang antroposentrisme yang membatasi keberlakuan etika hanya pada komunitas manusia Salah satu versi teori ekosentrisme adalah teori etika lingkungan yang sekarang ini popular dikenal sebagai Deep Ecology. Sebagai sebuah istilah, Deep Ecology diperkenalkan oleh Arne Naess. Menurut Naess dalam Keraf bahwa Deep Ecology menuntut suatu etika baru yang tidak berpusat pada manusia, tetapi berpusat pada makhluk hidup seluruhnya dalam kaitan dengan upaya mengatasi persoalan lingkungan hidup. 
halus dan kompleks. Cara sistem-sistem ekologis ini mengorganisir diri sendiri telah teruji sangat handal untuk melestarikan kehidupan di planet bumi. ${ }^{23}$

Atas dasar kesadaran inilah manusia menata pola dan gaya hidupnya menjadi pola dan gaya hidup yang selaras dengan lingkungan hidup. Manusia lalu menggunakan kesadaran tersebut untuk menuntun hidupnya dalam segala dimensinya sampai menjadi sebuah budaya yang merasuki semua anggota masyarakat untuk akhirnya terciptalah sebuah masyarakat yangberkelanjutan. Secara khusus, Capra juga memaksudkan ecoliteracy sebagai keadaan di mana orang telah memahami prinsip-prinsip ekologi dan hidup sesuai dengan prinsipprinsip ekologi itu dalam menata dan membangun kehidupan bersama umat manusia di bumi ini dalam dan untuk mewujudkan masyarakat berkelanjutan. ${ }^{24}$

Masa depan Indonesia dan Pembangunan Berkelanjutan akan sangat bergantung pada melek ekologis yaitu paham akan prinsip ekologis dan menata hidup serta perilakunya sesuai dengan prinsip ini. Kesadaran harus menjadi suatu sistem yang bisa dimulai dari perilaku individu sampai dengan penataan struktural sistem politik, ekonomi, pendidikan, dan birokrasi. Secara lebih praktis bisa dimulai dari konsumsi kebutuhan pokok, konsumsi energi, penggunaan teknologi dan peralatan rumah tangga, perawatan rumah, rancangan bangun rumah dan kantor, pertanian, pengembangan mata pencaharian, pengembangan industri dan bisnis, pengelolaan kantor. ${ }^{25}$ Dengan demikian, masyarakat diajak untuk meninggalkan sikap antroposentrisme, untuk berprinsip pada ecoliteracy sesuai dengan etika bioesentrisme dan deep ecolology. Sesungguhnya masyarakat juga diajak untuk kembali pada kearifan lokal26 dalam memperlakukan alam. Kearifan lokal dalam mengelola lingkungan hidup, termuat dalam Undang-

\footnotetext{
${ }_{23}$ Agus Purwadianto, dkk, Jalan Paradoks; Visi Baru Fritjof Capra tentang Kearifan dan kehidupan Modern, Teraju, Mizan, Bandung, 2004 hlm. 42-45. hlm. 83

${ }^{24}$ Sonny Keraf, Filsafat Lingkungan Hidup, Alam sebagai Sebuah Sistem Kehidupan, Kanisius, Yogyakarta, 2014,

${ }^{25}$ http://www.menlh.go.id/melek-ekologis/diakses tanggal 25 Mei 2015.

${ }^{26}$ Sesuai dengan pendapat yang disampaikan oleh I Ketut Gobyah, kearifan lokal (local genius) adalah kebenaran yang telah mentradisi atau ajeg dalam suatu daerah. Kearifan lokal merupakan perpaduan antara nilainilai suci firman Tuhan dan berbagai nilai yang ada. Lihat I Ketut Gobyah, Berpijak Pada Kearifan Lokal, http: www.balipos.co.id, diakses tanggal 3 September 2013. Nyoman Sirtha menjelaskan bahwa kearifan lokal dalam masyarakat dapat berbentuk nilai, norma, etika, kepercayaan, adat istiadat, hukum adat dan aturan-aturan khusus yang mempenyai fungsi bermacam-macam, antara lain memberikan informasi tentang beberapa fungsi dan makna kearifan lokal yang berfungsi untuk konservasi dan pelestarian lingkungan Irene Mariene, Kearifan Lokal Pengelolaan Hutan Adat, Raja Grafindo Persada, Jakarta, 2014, hlm. 112-113.
} 
Undang No. 32 Tahun 2009 Tentang Perlindungan Dan Pengelolaan Lingkungan Hidup (selanjutnya menggunakan istilah UUPPLH). Pasal 1 angka 30 UUPPLH menjelaskan kearifan lokal adalah nilai-nilai luhur yang berlaku dalam tata kehidupan masyarakat untuk antara lain melindungi dan mengelola lingkungan hidup secara lestari, yang selanjutnya kearifan lokal juga menjadi salah satu asas dalam perlindungan dan pengelolaan lingkungan hidup yang dimuat dalam Pasal 2 huruf (1) UUPPLH dan diperjelas dalam penjelasannya, yang dimaksud dengan asas kearifan lokal adalah bahwa dalam perlindungan dan pengelolaan lingkungan hidup harus memperhatikan nilai-nilai luhur yang berlaku dalam tata kehidupan masyarakat.

Istilah kearifan lokal di beberapa undang-undang disebutkan tersendiri dengan Masyarakat Hukum Adat (MHA), hukum adat ataupun budaya, menunjukkan bahwa berdasarkan hal itu kearifan lokal lebih luas dari MHA ataupun hukum adat karena tidak hanya terikat dengan adanya suatu masyarakat khusus yang berhubungan dengan otoritas adat tertentu. Sesuai dengan pendapat Ter Haar, masyarakat hukum adat merupakan kesatuan manusia yang teratur dan menetap di daerah tertentu, mempunyai pengurus-pengurus yang para anggotanya tidak mempunyai pikiran atau kecenderungan untuk melepaskan diri dari ikatan itu untuk selamanya. ${ }^{27}$

Misalnya Nagari dalam masyarakat Minangkabau, dusun dan marga dalam masyarakat Palembang yang mempunyai struktur tersendiri di luar negara. ${ }^{28}$ Kearifan lokal dapat ditemui dalam nyanyian, pepatah, sesanti, petuah, semboyan dan lainnya. Lebih menggambarkan fenomena spesifik yang biasanya menjadi ciri khas komunitas kelompok tertentu, misalnya alon-alon asalkelakon, nyulet makanan pada masyarakat Bangka agar tidak kepon yang merupakan istilah lokal masyarakat Bangka yaitu terjadi kecelakaan pada orang yang menolak makanan atau minumanyang ditawarkan karena dianggap menolak rejeki. Kepon juga bisa terjadi karena tidak terlaksana keinginan pada makanan, nabat di tengah hutan kelekak

${ }^{27}$ Ibid, hlm. 83.

${ }^{28}$ Ade Saptomo, Hukum dan Kearifan Lokal, Revitalisasi Hukum Adat Nusantara, Gramedia Widiasarana Indonesia, Jakarta, 2010, hlm. 13-15. 
merupakan salah satu kearifan lokal masyarakat Bangka yang bermana etika bagi kelestarian dan keberlanjutan lingkungan, khususnya akan keberadaan hutan.

Tabel

Kearifan Lokal Dalam Undang-Undang

\begin{tabular}{|c|c|c|}
\hline $\mathrm{NO}$ & UNDANG-UNDANG & PASAL \\
\hline 1. & $\begin{array}{l}\text { Undang-Undang No. } 27 \text { Tahun } \\
2007 \text { tentang Pengelolaan Wilayah } \\
\text { Pesisir Dan Pulau-Pulau Kecil' }\end{array}$ & $\begin{array}{l}\text { Pasal } 1 \text { angka } 36 \text { Kearifan Lokal adalah nilai- } \\
\text { nilai luhur yang masih berlaku dalam tata } \\
\text { kehidupan masyarakat. } \\
\text { Pasal 61(1) Pemerintah mengakui, } \\
\text { menghormati, dan melindungi hak-hak } \\
\text { Masyarakat Adat, Masyarakat Tradisional, dan } \\
\text { Kearifan Lokal atas Wilayah Pesisir dan Pulau- } \\
\text { Pulau Kecil yang telah dimanfaatkan secara } \\
\text { turun-temurun. } \\
\text { Pasal } 61 \text { (2) Pengakuan hak-hak Masyarakat } \\
\text { Adat, Masyarakat Tradisional, dan Kearifan } \\
\text { Lokal nsebagaimana dimaksud pada ayat (1) } \\
\text { dijadikan acuan dalam Pengelolaan Wilayah } \\
\text { Pesisir dan Pulau-Pulau Kecil yang } \\
\text { berkelanjutan. } \\
\text { Penjelasan Pasal } 64 \text { (2) Penyelesaian sengketa } \\
\text { di luar pengadilan dilakukan para pihak } \\
\text { dengan cara konsultasi, penilaian ahli, } \\
\text { negosiasi, mediasi, konsiliasi, arbitrase atau } \\
\text { melalui adat istiadat/kebiasaan/kearifan }\end{array}$ \\
\hline 2. & $\begin{array}{lrr}\text { Undang-Undang } & \text { Nomor } 13 \\
\text { Tahun } 2012 & \text { tentang } \\
\text { Keistimewaan } & \text { Daerah } & \text { Istimewa } \\
\text { Yogyakarta } & & \end{array}$ & $\begin{array}{l}\text { Pasal } 4 \text { huruf } g \text {, Pengaturan Keistimewaan } \\
\text { DIY dilaksanakan berdasarkan asas: } \\
\text { pendayagunaan kearifan lokal } \\
\text { Pasal } 7 \text { (3) Penyelenggaraan kewenangan } \\
\text { dalam urusan Keistimewaan didasarkan pada } \\
\text { nilai-nilai kearifan lokal dan keberpihakan } \\
\text { kepada rakyat. }\end{array}$ \\
\hline 3. & $\begin{array}{l}\text { Undang-Undang Nomor } 6 \text { Tahun } \\
2014 \text { tentang Desa }\end{array}$ & $\begin{array}{l}\text { Pasal } 24 \text { huruf i, Penyelenggaraan } \\
\text { Pemerintahan Desa berdasarkan asas kearifan } \\
\text { lokal. } \\
\text { Pasal } 81 \text { (3) Pelaksanaan Pembangunan Desa } \\
\text { dilakukan dengan memanfaatkan kearifan } \\
\text { lokal dan sumber daya alam Desa. } \\
\text { Penjelasan umum angka } 10 \text { UU desa } \\
\text { Pembangunan Desa dilaksanakan oleh } \\
\text { Pemerintah Desa dan masyarakat Desa } \\
\text { dengan semangat gotong royong serta } \\
\text { memanfaatkan kearifan lokal dan sumber } \\
\text { daya alam Desa. }\end{array}$ \\
\hline
\end{tabular}




\begin{tabular}{|c|c|c|}
\hline & & $\begin{array}{l}\text { Penjelasan Pasal } 24 \text { Huruf i yang dimaksud } \\
\text { dengan "kearifan lokal" adalah asas yang } \\
\text { menegaskan bahwa di dalam penetapan } \\
\text { kebijakan harus memperhatikan kebutuhan } \\
\text { dan kepentingan masyarakat Desa. }\end{array}$ \\
\hline 4. & $\begin{array}{l}\text { Undang-Undang No. } 18 \text { Tahun } \\
2012 \text { tentang Pangan }\end{array}$ & $\begin{array}{l}\text { Pasal } 1 \text { angka } 3 \text { Kemandirian Pangan adalah } \\
\text { kemampuan negara dan bangsa dalam } \\
\text { memproduksi Pangan yang beraneka ragam } \\
\text { dari dalam negeri yang dapat menjamin } \\
\text { pemenuhan kebutuhan Pangan yang cukup } \\
\text { sampai di tingkat perseorangan dengan } \\
\text { memanfaatkan potensi sumber daya alam, } \\
\text { manusia, sosial, ekonomi, dan kearifan lokal } \\
\text { secara bermartabat. } \\
\text { Pasal } 1 \text { Angka 15. Pangan Pokok adalah } \\
\text { Pangan yang diperuntukkan sebagai } \\
\text { makanan utama sehari-hari sesuai dengan } \\
\text { potensi sumber daya dan kearifan lokal. } \\
\text { Pasal } 1 \text { angka 17. Pangan Lokal adalah } \\
\text { makanan yang dikonsumsi oleh masyarakat } \\
\text { setempat sesuai dengan potensi dan kearifan } \\
\text { lokal. } \\
\text { Pasal } 33 \text { (2) Pemerintah dan Pemerintah } \\
\text { Daerah memfasilitasi pengembangan } \\
\text { Cadangan Pangan Masyarakat sesuai dengan } \\
\text { kearifan lokal. } \\
\text { Pasal } 58 \text { (2) Bantuan Pangan sebagaimana } \\
\text { dimaksud pada ayat (1) dilakukan dengan } \\
\text { mengutamakan produksi dalam negeri dan } \\
\text { kearifan lokal. } \\
\text { Pasal } 60 \text { (2) Penganekaragaman konsumsi } \\
\text { Pangan sebagaimana dimaksud pada ayat (1) } \\
\text { diarahkan untuk meningkatkan kesadaran } \\
\text { masyarakat dan membudayakan pola } \\
\text { konsumsi Pangan yang beragam, bergizi } \\
\text { seimbang, dan aman serta sesuai dengan } \\
\text { potensi dan kearifan lokal. } \\
\text { Penjelasan umum angka I, Pemenuhan } \\
\text { konsumsi Pangan tersebut } \\
\text { mengutamakan produksi dalam negeri } \\
\text { dengan memanfaatkan sumber daya dan } \\
\text { kearifan lokal secara optimal. }\end{array}$ \\
\hline 5. & $\begin{array}{l}\text { Undang-Undang No. } 32 \text { Tahun } \\
2009 \text { tentang Perlindungan dan } \\
\text { Pengelolaan Lingkungan Hidup }\end{array}$ & $\begin{array}{l}\text { Pasal } 1 \text { angka } 30 \text {. Kearifan lokal adalah nilai- } \\
\text { nilai luhur yang berlaku dalam tata } \\
\text { kehidupan masyarakat untuk antara lain } \\
\text { melindungi dan mengelola lingkungan hidup } \\
\text { secara lestari. }\end{array}$ \\
\hline
\end{tabular}




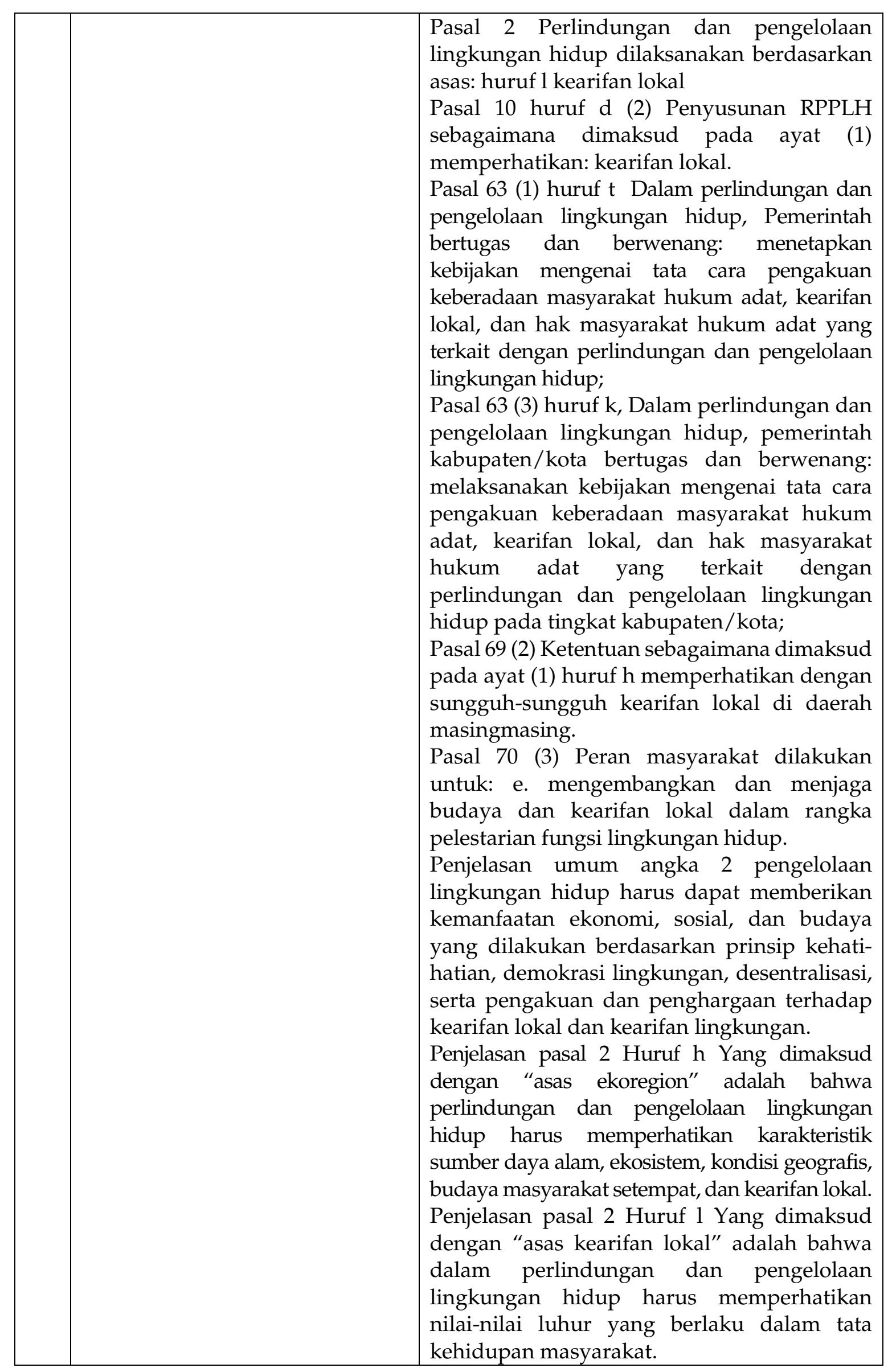




\begin{tabular}{|c|c|c|}
\hline & & $\begin{array}{l}\text { Penjelasan pasal } 10 \text { (2) Huruf d Kearifan lokal } \\
\text { dalam ayat ini termasuk hak ulayat yang } \\
\text { diakui oleh DPRD. } \\
\text { Penjelasan Pasal } 62 \text { Ayat (1) Sistem informasi } \\
\text { lingkungan hidup memuat, antara lain, } \\
\text { keragaman karakter ekologis, sebaran } \\
\text { penduduk, sebaran potensi sumber daya } \\
\text { alam, dan kearifan lokal. } \\
\text { Penjelasan Pasal } 69 \text { Ayat (2) Kearifan lokal yang } \\
\text { dimaksud dalam ketentuan ini adalah } \\
\text { melakukan pembakaran lahan dengan luas } \\
\text { lahan maksimal } 2 \text { hektare per kepala keluarga } \\
\text { untuk ditanami tanaman jenis varietas lokal dan } \\
\text { dikelilingi oleh sekat bakar sebagai pencegah } \\
\text { penjalaran api ke wilayah sekelilingnya. }\end{array}$ \\
\hline 6. & $\begin{array}{l}\text { Undang-Undang } 32 \text { Tahun } 2014 \\
\text { tentang Kelautan }\end{array}$ & $\begin{array}{l}\text { Pasal } 28 \text { (3) Pengembangan wisata bahari } \\
\text { dilaksanakan dengan mempertimbangkan } \\
\text { aspek kepentingan masyarakat lokal dan } \\
\text { kearifan lokal serta harus memperhatikan } \\
\text { kawasan konservasi perairan. } \\
\text { Pasal } 36 \text { (3) huruf c, Kebijakan budaya bahari } \\
\text { dilakukan melalui pengembangan teknologi } \\
\text { dengan tetap mempertimbangkan kearifan lokal. } \\
\text { Pasal } 70 \text { (4) huruf a, Peran serta masyarakat } \\
\text { dapat dilakukan melalui partisipasi dalam } \\
\text { melestarikan nilai budaya dan wawasan } \\
\text { bahari serta merevitalisasi hukum adat dan } \\
\text { kearifan lokal di bidang Kelautan }\end{array}$ \\
\hline 7. & 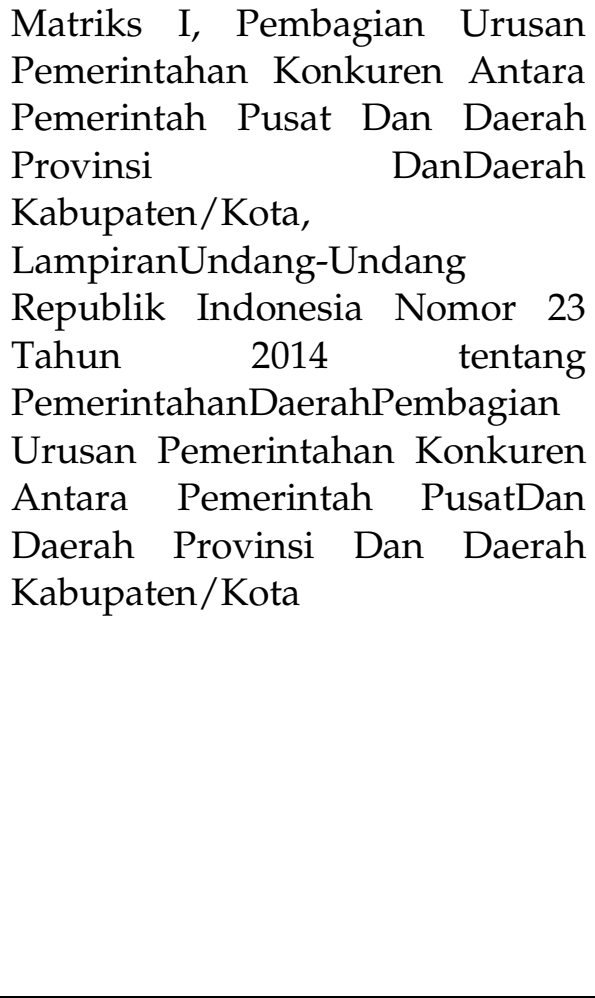 & $\begin{array}{l}\text { huruf K Pembagian Urusan Pemerintahan } \\
\text { Bidang Lingkungan Hidup angka 7, Pengakuan } \\
\text { keberadaan masyarakat hukumadat (MHA), } \\
\text { kearifan lokal dan hak MHA yang terkait } \\
\text { dengan PPLH Kewenangan Pemerintah Pusat; } \\
\text { a. Penetapan pengakuan MHA, kearifan lokal } \\
\text { atau pengetahuan tradisional dan hak MHA } \\
\text { terkait dengan PPLH yang berada di } 2 \text { (dua) } \\
\text { atau lebih Daerah provinsi. b. Peningkatan } \\
\text { kapasitas MHA, kearifan lokal } \\
\text { ataupengetahuan tradisionaldan hak MHA } \\
\text { terkait dengan PPLH yang berada di } 2 \text { (dua) } \\
\text { atau lebih Daerah provinsi. } \\
\text { Kewenangan Pemerintah Daerah Provinsi : } \\
\text { a. Penetapan pengakuan MHA, kearifan lokal } \\
\text { atau pengetahuan tradisional dan hak } \\
\text { kearifan lokal atau pengetahuan tradisional } \\
\text { dan hak MHAterkait dengan PPLH yang } \\
\text { berada di dua atau lebih Daerah } \\
\text { kabupaten/kota dalam } 1 \text { (satu) Daerah } \\
\text { provinsi. }\end{array}$ \\
\hline
\end{tabular}




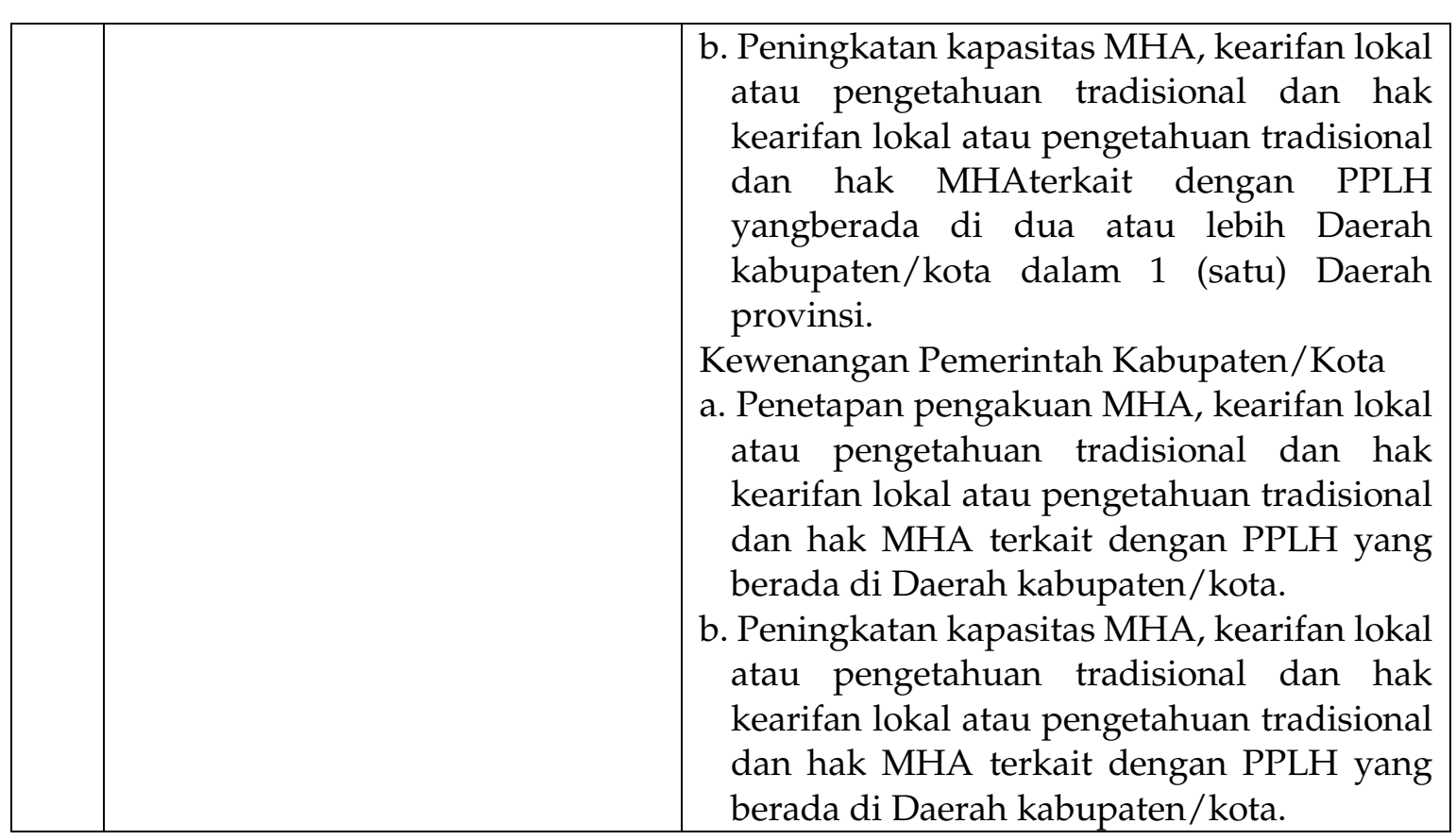

Sumber: bahan diolah sendiri oleh Peneliti.

\section{Kearifan Lokal Tambang Rakyat sebagai Wujud Ecoliteracy di Kabupaten Bangka}

Ketentuan dalam konstitusi Pasal 32 ayat (2) UUDNRI Tahun 1945 telah memberikan penegasan bahwa negara mengakui dan menghormati kearifan lokal masyarakat Indonesia, yang berarti menghormati, mengakui dan menaati keberadaan kearifan lokal masyarakat. ${ }^{29}$ Kearifan lokal yang merupakan nilai, tumbuh dan berkembang pada masyarakat lokal Indonesia yang menurut Esmi Warassih nilai itu bagi masyarakat telah tertanam dalam jiwa/spirit yang dibangun oleh masyarakat itu dan tidak menjadikan dia hilang atau punah. ${ }^{30}$

Kearifan lokal di Indonesia sangat beragam, menyebar keseluruh wilayah Indonesia. Kearifan lokal ini salah satunya dapat dijumpai di Kabupaten Bangka, terkait dengan aktivitas tambang rakyat. Karena kearifan lokal mencakup pengetahuan masyarakat yang unik berbasis pada pengetahuan tertentu termasuk pertambangan demi mempertahankan kesinambungan kehidupan mereka. Di Kabupaten Bangka ada kearifan lokal timah ampak atau timah yang di asal atau

\footnotetext{
${ }^{29}$ Baca juga Akhmad Elvian, Memarung, Panggung, Bubung, Kampung \& Nganggung, Dinas Kebudayaan, Pariwisata, Pemuda Dan Olahraga Kota Pangkalpinang, 2015, hlm. v-vi.

${ }^{30}$ Esmi Warassih Pujirahayu, "Keberagaman Bukan Keseragaman: Hukum Haruskah Memihak", Makalah dalam Seminar Nasional dan Bedah Buku "Biarkan Hukum Mengalir”, FH-Undip Semarang, 25 Mei 2008,hlm. 2.
} 
timah kopong. Suatu kondisi dimana timah yang ada sangat ringan kalau ditimbang sehingga tidak berharga atau tidak bisa dijual, sama halnya dengan pasir biasa. Timah ampak diyakini dan diakui masyarakat akibat dari tindakan atau perbuatan yang menjadi pantangan (istilah lokal)/ larangan dalam menambang telah dilanggar oleh penambang. ${ }^{31}$

Ada sebuah kearifan lokal demi menyelamatkan lingkungan Kabupaten Bangka khususnya dan pada umumnya lingkungan Propinsi Kepulauan Bangka Belitung yaitu timah yang ada sudah dihampakan, dalam arti kualitas dan kuantitas timahnya sudah tidak baik lagi, atau dalam istilah masyarakat desa setempat disebut dengan diasal.

Sejarahnya, pada zaman penjajahan Belanda di Bangka dan zaman masuknya etnis Cina dari Tiongkok ke Bangka telah terjadi eksploitasi pasir timah di Bangka. untuk wilayah yang diasal, yang belum pernah dieksploitasi. Zaman penjajahan Belanda di Bangka dan zaman masuknya etnis China dari Tiongkok ke Bangka telah terjadi eksploitasi pasir timah di Bangka. ${ }^{32}$

\section{Gambar 33}

Peta Potensi Timah Bangka Tahun 1813

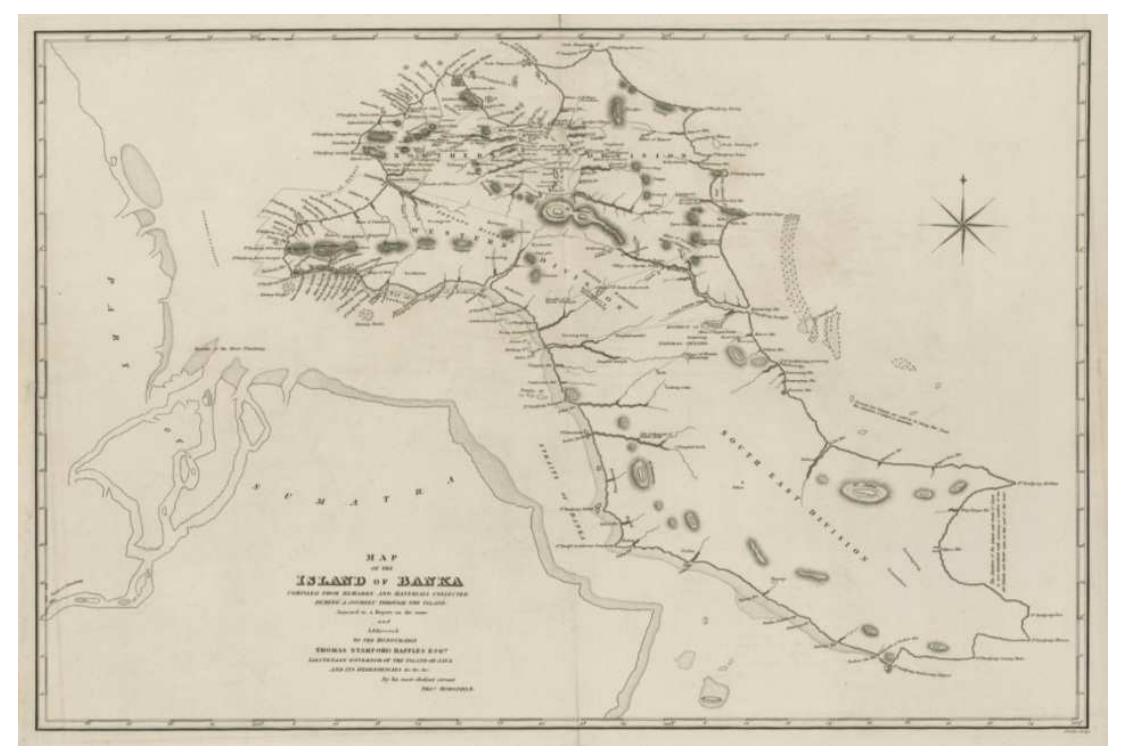

${ }^{31}$ Hasil Penelitian di Lokasi Penelitian

${ }^{32}$ Hasil wawancara dengan beberapa tokoh masyarakat dan ahli sejarah di Kabupaten Bangka, 11 November 2015 di Kecamatan Sungailiat dan Kecamatan Bakam, Kabupaten Bangka.

33 Akhmad Elvian, Perang Bangka Tahun 1812-1851 Masehi, Dinas Kebudayaan, Pariwisata, Pemuda dan Olahraga Kota Pangkalpinang, 2012, hlm. 65. 
Peta tersebut dibuat pada masa kekuasaan Inggris, Pulau Bangka dijadikan atas tiga divisi yang didasarkan pada pembagian wilayah eksplorasi atau penambangan timah, dibandingkan pada pembagian wilayah berdasarkan kepentingan pemerintahan. Pembagian tersebut yaitu pada bagian utara meliputi wilayah Jebus, Belinyu, Sungailiat, Merawang, (merupakan wilayah Kabupaten Bangka), kemudian wilayah Barat Pulau Bangka meliputi wilayah Mentok, Belo, Kotawaringin, dan terakhir wilayah Bagian Timur pulau Bangka yang meliputi hampir separuh Pulau Bangka yaitu Pangkalpinang, Sungaiselan, Bangkakota, Paku, Permis, Olim dan Toboali. ${ }^{34}$ Peta tersebut memberikan penjelasan bahwa seluruh Pulau Bangka termasuk Kabupaten Bangka mengandung kekayaan alam berupa timah, namun dengan pertimbangan keberlanjutan lingkungan untuk masa mendatang, maka oleh orang terdahulu ada beberapa wilayah yang diampak sedang ada juga yang tidak diampak dengan pertimbangan sebagai lahan pertanian dan bercocok tanam.

Berdasarkan hasil penelitian, tidak ada ketentuan dari pemerintah daerah untuk mengadopsi kearifan lokal yang ada sebagaimana yang telah diidentifikasi dalam latar belakang pada penelitian ini dimana ada beberapa wilayah antara lain Desa Balunijuk dan Desa Jade Kecamatan Merawang, Desa Mabet dan Desa Dalil Kecamatan Bakam, Desa Petaling Kecamatan Mendo Barat, yang sama sekali tidak tersentuh oleh aktivitas pertambangan timah khususnya TI, karena timah di wilayah tersebut sudah di ampak.

Di beberapa wilayah tersebut tidak ada aktivitas pertambangan, karena menurut masyarakat setempat, timahnya ampak. ${ }^{35}$ Jika di wilayah yang tidak tersentuh oleh aktivitas tambang rakyat, timah menjadi ampak tersebut karena memang sengaja diampak atau diasal oleh orang terdahulu untuk kelangsungan lingkungan hidup sehingga anak keturunan mereka tetap bisa memanfaatkan lingkungan hidup untuk berladang yang menjadi sumber mata pencaharian masa itu. ${ }^{36}$ Tidak adanya aktivitas pertambangan di beberapa wilayah di atas, karena

34 Hasil Wawancara dengan Akhmad Elvian, tanggal 08 April 2016, Ahli Sejarah Kepulauan Bangka Belitung yang saat wawancara menjabat sebagai Kepala Dinas Kebudayaan, Pariwisata, Pemuda dan Olahraga Kota Pangkalpinang. Ibid., hlm. 66.

35 Hasil wawancara dan observasi partisipatoris di lokasi penelitian.

${ }^{36}$ Ibid. 
timahnya sudah ampak menyebabkan lingkungan disana tetap terjaga kelestariannya. Sesuai dengan pendapat Sonny Keraf, bahwa kearifan lokal adalah semua bentuk pengetahuan, keyakinan, pemahaman,wawasan atau etika yang menuntun perilaku manusia dalam kehidupan di dalam komunitas ekologis, ${ }^{37}$ timah ampak sejalan dengan maksud untuk melestarikan lingkungan.

Hal itu senada dengan konsep "ecoliteracy", sebuah strategi untuk menggerakkan masyarakat luas agar bisa memahami pola pandang baru atas realitas kehidupan bersama mereka di planet bumi dan melakukan pembaruanpembaruan yang diperlukan. Hal tersebut didasarkan pada pemahaman bahwa kehidupan bersama di planet bumi harus dipandang bukan lagi secara mekanistik melainkan secara ekologis serta sistemik. Jadi apa yang perlu dipahami dari ecoliteracy adalah wisdom of nature (kebijaksanaan alam) yang digambarkan oleh Fritjof Capra sebagai kemampuan sistem-sistem ekologis planet bumi mengorganisir dirinya sendiri melalui cara-cara halus dan kompleks. Cara sistemsistem ekologis ini mengorganisir diri sendiri telah teruji sangat handal untuk melestarikan kehidupan di planet bumi. ${ }^{38}$ Jadi ada pembagian wilayah mana yang boleh ditambang dan mana yang tidak, bermaksud dengan mengadopsi sistem pengelolaan dari alam agar tetap seimbang.

Jika ditinjau di wilayah yang timahnya tidak ampak, lingkungan Kabupaten Bangka tersebut cenderung rusak akibat aktivitas tambang rakyat yang ditinggalkan begitu saja. Adanya keinginan ekonomis untuk mendapatkan penghasilan cepat dan sifat konsumtif penambang, ditambah dengan ketidakpedulian dari pemerintah dan masyarakat terhadap lingkungan merupakan salah satu alasan dibalik rusaknya kawasan tersebut. ${ }^{9}$ Hal itu terkait dengan cara pandang masyarakat Kabupaten Bangka dimana dijelaskan oleh Sony Keraf bahwa cara pandang tersebut memperkuat dominasi manusia atas alam. Karena alam hanya dilihat sebagai obyek untuk dikaji, dianalisis, dimanipulasi, direkayasa dan dieksploitasi masyarakat Kabupaten Bangka.

\footnotetext{
${ }^{37}$ Sony Keraf, Etika Lingkungan, Kompas, Jakarta, 2006, hlm. 289

38 Agus Purwadianto, dkk, Jalan Paradoks; Visi Baru Fritjof Capra tentang Kearifan dan kehidupan Modern, Teraju, Mizan, Bandung, 2004, hlm. 42-45.

${ }^{39}$ Hasil wawancara dan observasi partisipatoris di lokasi penelitian.
} 
Atas dasar dan digerakkan oleh kesadaran inilah manusia menata pola dan gaya hidupnya menjadi pola dan gaya hidup yang selaras dengan lingkungan hidup. Manusia lalu menggunakan kesadaran tersebut untuk menuntun hidupnya dalam segala dimensinya sampai menjadi sebuah budaya yang merasuki semua anggota masyarakat untuk akhirnya terciptalah sebuah masyarakat yang berkelanjutan.

\section{Penutup}

Berdasarkan pemaparan di atas dapat disimpulkan bahwa: pertama, membangun ecoliteracy untuk lingkungan berkelanjutan dengan cara meninjau kearifan lokal mengelola lingkungan hidup pada masyarakat lokal atau setempat. Kedua, kearifan lokal tambang rakyat berupa timah ampak harus dilestarikan dan dipergunakan sebagai wujud ecoliteracy di Kabupaten Bangka untuk lingkungan berkelanjutan.

\section{Daftar Pustaka}

\section{Buku}

Ade, Saptomo, Hukum Dan Kearifan Lokal, Revitalisasi Hukum Adat Nusantara, Gramedia Widiasarana Indonesia, Jakarta, 2010.

Agus, Purwadianto, dkk, Jalan Paradoks; Visi Baru Fritjof Capra tentang Kearifan dan kehidupan Modern, Teraju, Mizan, Bandung, 2004.

Akhmad, Elivan, Perang Bangka Tahun 1812-1851 Masehi, Dinas Kebudayaan, Pariwisata, Pemuda dan Olahraga Kota Pangkalpinang, 2012. , Memarung, Panggung, Bubung, Kampung \& Nganggung, Dinas Kebudayaan, Pariwisata, Pemuda Dan Olahraga Kota Pangkalpinang, 2015

B.B. Mitchel, Setiawan dan Dwita Hadi Rahmi, Pengelolaan Sumber Daya dan Lingkungan, Gajah Mada University Press, Yogyakarta, 2007.

Chapman Audrey, R., Rodney L. Petersen, Barbara Smith Moran, Bumi yang terdesak; Perspektif Ilmu dan Agama mengenai Konsumsi, Populasi, dan Keberlanjutan, Mizan Bandung. 2007.

D. Negara, Purnawan, Dekonstruksi kebijakan Pengelolaan Kawasan Tengger Berbasis Nilai Komunal Ekologios Dalam Perspektif Sosio Legal, Disertasi Program Doktor Ilmu Hukum, Undip, 2014. 
Erman, Erwiza, Menguak Sejarah Timah Bangka Belitung, Penerbit Ombak, Yogyakarta, 2009.

Esmi Pujirahayu, Warassih, "Keberagaman Bukan Keseragaman: Hukum Haruskah Memihak", Makalah dalam Seminar Nasional dan Bedah Buku "Biarkan Hukum Mengalir", FH-Undip Semarang, 25 Mei 2008.

Fritjof, Capra, Jaring-Jaring Kehidupan : Visi Baru Epistemologi dan Kehidupan, Fajar Pustaka Baru, Yogyakarta, 2002.

Irene, Mariene, Kearifan Lokal Pengelolaan Hutan Adat, Raja Grafindo Persada, Jakarta, 2014.

Iskandar, Zulkarnain, Konflik di Kawasan Pertambangan Timah di Bangka Belitung, Penerbit LIPI Press, 2005.

Keraf, Sonny, Etika Lingkungan, Kompas, Jakarta, 2006.

Filsafat Lingkungan Hidup Alam Sebagai Sebuah Sistem Kehidupan, Kanisius, Yogyakarta, 2014

Maimunah, Siti, Negara Tambang Dan Masyarakat Adat, Perspektif HAM Dalam Pengelolaan Pertambangan Yang Berbasis Lingkungan Dan Kearifan Lokal, Intrans Publising, Malang.

Sastrosupeno, S, Manusia, Alam dan Lingkungan.Proyek Penulisan dan Penerbitan Buku/Majalah Pengetahuan Umum dan Profesi, Departemen Pendidikan dan Kebudayaan, 1984

\section{Perundang-Undangan.}

UUDNRI 1945

Undang-Undang No. 32 Tahun 2009 tentang Perlindungan Dan Pengelolaan Lingkungan Hidup

Undang-Undang No. 27 Tahun 2007 tentang Pengelolaan Wilayah Pesisir Dan Pulau-Pulau Kecil.

Undang-Undang Nomor 13 Tahun 2012 tentang Keistimewaan Daerah Istimewa Yogyakarta

Undang-Undang Nomor 6 Tahun 2014 tentang Desa.

Undang-Undang No. 18 Tahun 2012 tentang Pangan.

Undang-Undang 32 Tahun 2014 tentang Kelautan.

Matriks I, Pembagian Urusan Pemerintahan Konkuren Antara Pemerintah Pusat dan Daerah Provinsi DanDaerah Kabupaten/Kota, LampiranUndangUndang Republik Indonesia Nomor 23 Tahun 2014 tentang Pemerintahan Daerah Pembagian Urusan Pemerintahan Konkuren Antara Pemerintah Pusat Dan Daerah Provinsi Dan Daerah Kabupaten/Kota. 


\section{Internet}

Hayati Tri, Perizinan Pertambangan Di Era Reformasi Pemerintahan Daerah Studi Tentang Perizinan Pertambangan Timah di Pulau Bangka, Disertasi UI, 2011, http://lib.ui.ac.id/file?file=digital/20305841-D\%201270-

Perizinan\%20pertambangan-full\%20text.pdf, diakses tanggal 07 Oktober 2014.

Gobyah I Ketut, Berpijak Pada Kearifan Lokal, http: www.balipos.co.id, diakses tanggal 3 September 2013.

http:/ / www.bangka.go.id/content.php?id_content=kondisi_geografis, diakses 05 Maret 2015.

http:/ / www.menlh.go.id/melek-ekologis/diakses tanggal 25 Mei 2015.

\section{Surat Kabar}

Kementerian Negara Lingkungan Hidup, Majalah Serasi, Deputi Bidang Komunikasi Lingkungan dan Pemberdayaan Masyarakat, Jakarta,Januari, 2006

Kompas, Rabu, 27 Januari 2016. 